\title{
COMPARATIVE STUDY OF NEWAR AND JAPANESE CLASSIFIERS Arun Shrestha*
}

\section{ABSTRACT}

This paper compares and contrasts the numeral classifier systems of two genetically unrelated languages: Newār of Kathmandu and "Hyoujungo", Japanese spoken in Tokyo, the defacto official language of Japan.

It is not the case either in Newār or in Japanese that nouns in general can be directly quantified by a number. For example, in Newār one cannot say *ni $\boldsymbol{c h} \tilde{e}$ two house "Two houses" for 'two houses'. Rather, one must say $\boldsymbol{n i}-\boldsymbol{k} \boldsymbol{h} \overline{\boldsymbol{a}}$ chẽ "two-CL house" Two houses".

The noun $\boldsymbol{c h} \tilde{\mathrm{e}}$ 'house' requires that the numeral classifier $\boldsymbol{- k} \boldsymbol{h} \overline{\mathrm{a}}$ be affixed to numerals used for counting houses. One might say that chẽ 'house' is not conceived of as a separate countable entity. Only when the unit $-\boldsymbol{k} \boldsymbol{h} \overline{\mathbf{a}}$ ' $\mathrm{CL}$ ' is suffixed to the number do we have a countable entity.

Numeral classifiers: The choice of noun determines the choice of classifier both in Newāri and in Japanese. By looking at the nouns associated with a given classifier it is possible to identify the way in which a noun selects its classifier. In Newār there are three different ways in which nouns select their classifiers (1) according to semantic parameters (as when sentient nouns select the classifier - $\boldsymbol{m h a}$, (2) by unique lexical collocation (as when $\boldsymbol{c h}$ ẽ 'house' selects $\boldsymbol{k} \boldsymbol{h} \bar{a}$ ' $C L$ ') and (3) by full or partial reduplication (as when ha: 'leaf' selects the head noun ha: itself, where as salakhwã: 'horse's hoof' selects -khwã:, only the latter portion of the head noun (Hale 2005).

These modes can be taken as the basis for a three-term typology of classifier selection: (1) semantic selection, (2) lexical selection, and (3) morphological selection. This paper provides a detailed comparison of Newār and Japanese classifiers within each of these three types of selection. Though all three types are attested in each language, there are mutual counterparts and skewings between the two languages.

\section{INTRODUCTION}

Japanese and Newār, though genetically unrelated do share a typological feature in that both are classifier languages. There are over 500 classifiers in Japanese and over 200 in Newār. Beginning attempts to compare the two systems have been made in the following four studies: The first, (Kiryu 2002) was a list of some 3,400 Newār words with Japanese glosses, in which classifiers receive some discussion. The second, (Shrestha 2004) was the first serious attempt at a comparison of the two classifier systems. The third, (Shrestha 2008) was a much more detailed contrastive study of the two systems. The fourth, also (Shrestha 2009) was a summary with special features prevalent in the classifiers of the two languages.

\footnotetext{
* Lecturer, Campus of International Languages, Tribhuvan University, Kathmandu, Nepal
} 
Though the three studies mentioned above are important contributions to our understanding of the two systems, the need still exists for a more comprehensive, definitive study designed to provide a basis for educational materials still needed for linguists, researchers, students and amateurs of this arena.

\section{METHODOLOGY}

Taking Arun Shrestha (2008) as the starting point, the aim of this research was to construct a more comprehensive, definitive study designed to provide a basis for educational materials still needed in the arena.

One important resource was Iida Asako and Machida Ken (2004) and the comprehensive listing of 554 Japanese numeral classifiers that it contains (Iida and Machida 2004). Further information was gleaned from the relevant literature and the internet.

\section{ESTABLISHING A BASIC TAXONOMY FOR EACH LANGUAGE Analytic Steps taken during Research}

The first step was to establish a basic taxonomy of classifiers for each of the two languages. It was possible to establish a similarity and contrast between classifiers according to the way head nouns of their respective numeral classifiers. Three types of classifiers of both languages were scrutinized.

The second step was to examine in detail the noun-classifier pairings belonging to each type of classifier.

The third step was to sort out the counterpart classifiers and counterpart skewings between Newār and Japanese.

\section{Three types of classifiers were identified in the two languages.}

Type 1: classifiers that are selected by nouns on the basis of certain semantic properties of the head noun, Type 2: classifiers that are selected by nouns on the basis of a unique lexical collocation, and Type3: nouns that construct their classifiers through the full or partial reduplication of the head noun.

For Type 1 analysis was made about what semantic parameters were involved, and how did these parameters differ between Japanese and Newār? One striking example of the contrast between languages was found for animate or sentient nouns. Where Newār used a single classifier, - $\boldsymbol{m} \boldsymbol{h} \boldsymbol{a}$, for all sentient nouns as well as for nouns referring to entities conventionally grouped with sentient nouns (such as dolls, scarecrows), Japanese animate nouns made their selection from a set of seven different classifiers, -tou, -hiki, -nin, -ri, -mei, -shi, and -wā. One then needed to ask what the basis was for this further differentiation among the animate nouns of Japanese and to what extent.

It was found, for example, that where classifiers were selected on the basis of the semantics of the head noun, there was a far greater chance for counterpart congruence between Newār and Japanese than where the classifiers were selected on the basis of unique ad-hoc selection or reduplication, where the semantic parameters played only a marginal role, if any.

For Type 2 while dealing with unique pairings of noun heads and numeral classifiers in Newar we had, as illustrated above, the classifier $\boldsymbol{- k} \boldsymbol{h} \bar{a}$, which collocates 
uniquely with the noun head chẽ 'house'. Since no other noun makes use of the classifier $\boldsymbol{- k} \boldsymbol{h} \bar{a}$ when counted, or is it a reduplication of $\boldsymbol{c h e ̃ . ~ S i m i l a r l y , ~ i n ~ J a p a n e s e ~ t h e ~}$ classifier -mon (門) collates uniquely with the noun head cannon.

For Type 3 distinctions were made between noun heads which reduplicate as a whole and those that are formed by partial reduplication.

\section{RESULTS}

\section{THE NeWAR TAXONOMY}

\section{Semantic Selection}

The following is a listing of Newār Type 1 classifiers. In the left-hand column are the Type 1 classifiers. In the middle column is the conventional gloss for that classifier and in the right-hand column is a sample of the head nouns which select that classifier.

\begin{tabular}{|c|c|c|}
\hline Classifier & Classifier Gloss & Noun Heads \\
\hline -ga: & $\begin{array}{l}\text { round objects, containers, } \\
\text { vehicles }\end{array}$ & $\begin{array}{l}\text { Stones, pearls, diamonds, cereals, } \\
\text { cabbages, eggs, cakes, garlics, onions, } \\
\text { cucumbers, oranges stomachs, buttocks, } \\
\text { watches, bottles, pillars, beams, the earth, } \\
\text { stars, volcanoes, soapcakes,pillows, bags, } \\
\text { cages, trunks, bells, hats, underwear, } \\
\text { cars, boats, ships, motor-bikes ... }\end{array}$ \\
\hline -gu: & $\begin{array}{l}\text { default classifier for } \\
\text { miscellaneous items }\end{array}$ & $\begin{array}{l}\text { countries, villages, towns, ponds, farms, } \\
\text { parks, tools, bricks, pieces of furniture, } \\
\text { shopsbuildings, palaces, families, } \\
\text { months, spectacles, monuments, tunnels, } \\
\text { graves ... }\end{array}$ \\
\hline$-m h a$ & $\begin{array}{l}\text { sentient beings and items } \\
\text { conventionally viewed as } \\
\text { sentient }\end{array}$ & $\begin{array}{l}\text { men, women, children, dogs, cats, horses, } \\
\text { cows, chickens, birds, insects, images, } \\
\text { scarecrows, dolls, ghosts, dieties, ... }\end{array}$ \\
\hline$-m \overline{\mathbf{a}}$ & plants & trees, shrubs, vines, \\
\hline$-p u$ & long thin objects & ropes, pieces of thread, stalks, \\
\hline$-p \overline{\mathbf{a}}$ & paired objects, flat objects & $\begin{array}{l}\text { eyes, hands, ears, legs, shoes, socks, } \\
\text { gloves...... }\end{array}$ \\
\hline -cā: & circular disc shaped objects & ear-rings, wheels, tablets \\
\hline -ku: & pieces & $\begin{array}{l}\text { wounds, scars, small broken or cut out } \\
\text { pieces of edible or non-edible objects, } \\
\text { splinters of glasses, room, kitchen, } \\
\text { garden, yard }\end{array}$ \\
\hline -pvā: & $\begin{array}{l}\text { electric lamps, stoves being } \\
\text { used for cooking, human } \\
\text { bodily orifices }\end{array}$ & $\begin{array}{l}\text { electric stoves, kerosene stoves, gas } \\
\text { stoves, anus, gutter, nostrils }\end{array}$ \\
\hline$-p t \bar{a}$ & cosmetics, seals & $\begin{array}{l}\text { vermillion mark, stamp(seal), black eye- } \\
\text { shadows }\end{array}$ \\
\hline -phuti & liquids and stains & Water drop, saline drop, ink drop \\
\hline -thi: & genus of inanimate objects & All kinds of sweets. \\
\hline $\begin{array}{l}\text {-tā (Hale and } \\
\text { Shresthachrya } \\
\text { 1973) }\end{array}$ & $\begin{array}{l}\text { species or items of } \\
\text { prescribed set of different } \\
\text { objects. }\end{array}$ & 'julvi', 'jeri', 'lālmon','laddu', etc. \\
\hline
\end{tabular}


The Japanese Taxonomy

Semantic Selection

\section{Parameters:}

Abstract nouns

Letters and documents for dispatch

Explosives and fire crackers

3-dimensional objects

Small ships

Yachts

Big ships

Items

Parts and copies

Ways of thinking

Elixirs, syrups

Powdered medicines

Capsules/Tablets

Suppositories

Stone walls, brick walls

Nights

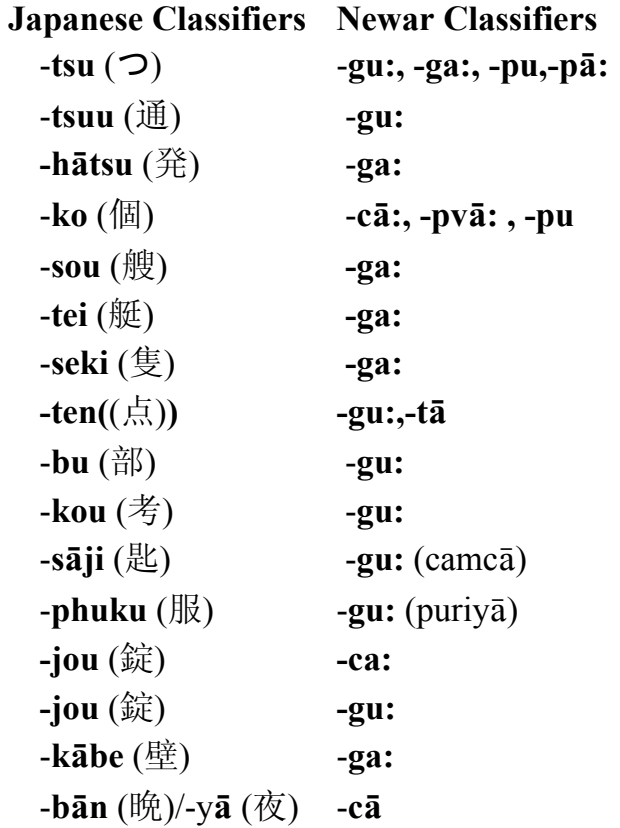

Lexical Selection in Newār

The following is a listing of Type 2 classifiers

\begin{tabular}{|c|c|c|}
\hline Classifier & Classifier Gloss & Noun Head \\
\hline$-k h \bar{a}$ & classifier for "house" & chẽ 'house' \\
\hline -thwā: & classifier for "cauliflower" & kāule 'cauliflower' \\
\hline
\end{tabular}

Lexical Selection in Japanese of Newār Type 2 classifiers

\begin{tabular}{|l|l|l|}
\hline Classifier & Classifier Gloss & Noun Head \\
\hline -mon (門) & classifier for “cannon” & tāihou 'cannon' \\
\hline
\end{tabular}

Morphological Selection in Newār

A listing of Newār Type 3 classifiers

\begin{tabular}{|c|c|c|}
\hline Classifier & $\begin{array}{l}\text { Reduplication } \\
\text { Type }\end{array}$ & Head with classifier \\
\hline -khwã: & Partial & $\begin{array}{l}\text { salakhwã: } \boldsymbol{n i -} \boldsymbol{k h w a ̃ :} \text { 'two horse's hooves' } \\
\text { (Hale and Shrestha 2005) }\end{array}$ \\
\hline$-t i$ & Full & $\boldsymbol{t i} \boldsymbol{n i - t i}$ 'two stitches' \\
\hline -kica: & Full & kica: cha- kica: 'a shadow' \\
\hline -duvā: & Partial & lukhāduvāa:cha- duvā: 'a courtyard entrance' \\
\hline -palā: & Full & palā: sva-palā: 'three steps \\
\hline -pva: & Partial & bhõ:pva: pe-pva: 'four bundles of papers' \\
\hline$-\mathbf{p} \overline{\mathbf{a}}$ & Full & $\boldsymbol{p} \overline{\boldsymbol{a}} \boldsymbol{k} \boldsymbol{h} \boldsymbol{u}$ - $\boldsymbol{p} \overline{\boldsymbol{a}}$ 'six feathers, six axes' \\
\hline$-\mathbf{p u}$ & Full & pu jhi- pu 'ten seeds' \\
\hline
\end{tabular}




\begin{tabular}{|c|c|c|}
\hline -pati: & Full & pati: $n y \bar{a}-$ pati: 'five fingers' \\
\hline$-\mathbf{p i}$ & Full & pi chapi'one placenta' \\
\hline -phi & Full & phi cha-phi'a layer of sand' \\
\hline -ha: & Full & $\boldsymbol{h a}: \boldsymbol{n i}-\boldsymbol{h a}$ : 'two leaves' \\
\hline -pva: & Full & pva: cha- pva: 'a swelling' \\
\hline -khvāẽ & Partial & pālikhvāẽ chakhvāẽ 'one footprint' \\
\hline -nakĩ & Parital & nakĩ chaki 'one iron nail' \\
\hline -mva: & Partial & parsimva: chamva: 'one pleat of a sari' \\
\hline$-\mathbf{p i}$ & Partial & durupi chapi 'one nipple' \\
\hline$-\mathbf{p i}$ & Partial & cupi chapi 'one knife / chopper ' \\
\hline -phi & Partial & tuphi chaphi 'a broom' \\
\hline -pvāa: & Partial & gvākhã:pvā: chapvāa: 'a niche' \\
\hline -pva: & Partial & durupva: chapva: 'a breast' \\
\hline -pvā: & Partial & simāpvā: chapvā: 'one crotch of a tree' \\
\hline -pvā: & Partial & dhãa:pvā: chapvāa: 'a gutter' \\
\hline$-\mathbf{m a ̄}$ & Partial & svã:mā chama 'a single plant' \\
\hline$-\mathbf{p i}$ & Partial & durupi chapi 'one nipple' \\
\hline
\end{tabular}

'Reduplications' in Japanese of Newār Type 3.1.3.1 classifiers

\begin{tabular}{|c|c|c|}
\hline -ori (折)-(pleat) & Full & (ori) hitoori (Tadao, 1989) \\
\hline -retsu(列)(row) & Full & (retsu) iciretsu \\
\hline -gyou (行) -(line of sentences) & Full & (gyou) icigyou \\
\hline -shijuku(雫 / 滴)-(drop) & Full & (shijuku) hitoshijuku \\
\hline -teki (滴) -(drop) & Full & (teki) itteki \\
\hline -ten (点) -(drop) & Full & (ten) itten \\
\hline $\begin{array}{l}\text {-tenteki ( 点 滴 ) (an intravenous drip } \\
\text { injection) }\end{array}$ & Partial & tenteki itteki \\
\hline -dānrāku (段落) (paragraph) & Full & (dānrāku) icidānrāku \\
\hline -seki (席) (seat) & Full & (seki) isseki \\
\hline \multicolumn{2}{|l|}{ Newār classifiers: Japanese counterparts } & Pictorial scripts \\
\hline -māi, kātāhou. & & 枚，片方 \\
\hline $\begin{array}{l}\text {-māi, -hon, -omote, -sāt } \\
\text {-jou, -furui, -cyāku, -m }\end{array}$ & & $\begin{array}{l}\text { 枚, 本, 面, 札 } \\
\text { 畳, 篩, 着, 面. }\end{array}$ \\
\hline -rin, -māi, -ko. & & 輪, 枚, 個 \\
\hline $\begin{array}{l}\text {-māi, -kyoku, -wā, -hen, } \\
\text {-hon, -tsubu }\end{array}$ & & $\begin{array}{l}\text { 枚, 曲, 話, 編 } \\
\text { 本, 粒 }\end{array}$ \\
\hline -kāsho, -kire, -hen, -hey & $\overline{\mathbf{a}},-\mathbf{m} \mathbf{a} \mathbf{I}$ & 所、切、片、部屋, 枚 \\
\hline -hon, -ko, -kāsho. & & 本, 個, 箇所 \\
\hline$-p t \overline{\mathbf{a}}$ & & 個. \\
\hline -kāsho, -teki, -shizuku. & & 箇所、滴、雫/滴 \\
\hline -shurui. & & 種類 \\
\hline -sārā -hin, -shoku. & & 皿品、色 \\
\hline
\end{tabular}




\section{Newār reduplicative classifiers}

\begin{tabular}{|c|c|}
\hline -kica: & - (shadow) \\
\hline$-\mathbf{t i}$ & - (stitch) \\
\hline -duvā: & - (door or entrance \\
\hline & of a court-yard) \\
\hline -palā: & - (step) \\
\hline - pva: & - (swelling, \\
\hline & - heap of/ pile of) \\
\hline - pā & - (feather, axe) \\
\hline$-\mathbf{p u}$ & - (seed) \\
\hline - pati: & - (finger) \\
\hline$-\mathbf{p i}$ & - (placenta) \\
\hline - phi & - (layer of dust, sand etc) \\
\hline - ha: & - (leaf) \\
\hline -pva: & - (a swelling) \\
\hline -khvāẽ & $\begin{array}{l}\text { - pālikhvāẽ chakhvāẽ } \\
\text { (one footprint) }\end{array}$ \\
\hline - nakĩ & $\begin{array}{l}\text { - nakĩ chakĩ } \\
\text { (one iron nail) }\end{array}$ \\
\hline - mva: & $\begin{array}{l}\text { - parsimva: chamva: } \\
\text { (one pleat of a sari) }\end{array}$ \\
\hline$-\mathbf{p i}$ & $\begin{array}{l}\text { - durupi chapi } \\
\text { (one nipple) }\end{array}$ \\
\hline$-\mathbf{p i}$ & $\begin{array}{l}\text { - pi chapi } \\
\text { (one placenta) }\end{array}$ \\
\hline$-\mathbf{p i}$ & $\begin{array}{l}\text { - cupi chapi } \\
\text { (a knife, a chopper) }\end{array}$ \\
\hline -phi & $\begin{array}{l}\text { - tuphi chaphi } \\
\text { (a broom) }\end{array}$ \\
\hline -pva: & $\begin{array}{l}\text { - bhõ: pva: chapva: } \\
\text { (a bundle of papers) }\end{array}$ \\
\hline -pva: & $\begin{array}{l}\text { - durupva: chapva: } \\
\text { (a breast) }\end{array}$ \\
\hline -pvā: & $\begin{array}{l}\text { - simāpvā: chapvaa: } \\
\text { (one crotch of a tree) }\end{array}$ \\
\hline -pvā: & $\begin{array}{l}\text { - dhã:pvā: chapvā: } \\
\text { (a gutter) }\end{array}$ \\
\hline$-\mathbf{m} \overline{\mathbf{a}}$ & $\begin{array}{l}\text { - svã̃:m:ā chamā } \\
\text { (a single plant) }\end{array}$ \\
\hline
\end{tabular}

Japanese counterparts Pictorial scripts

\section{-tsu}

-ko, -hon

-ki, -mon

-tsu, -ko, -ho

-kāsho

-ko, -yāmā

-māi, -cyou

-ko, -tsubu

-hon

- tsu

-sou

-māI

-ko, -kāsho

-tsu , -ko

-hon

-ori

-tsu

- tsu

-cyou, -hon

-hon

個, 本

基, 門

つ, 個, 歩

箇所,

個, 山

枚, 丁

個, 粒

本

$\supset$

層

枚

個, 箇, 所

つ, 個

本

折

-tsutsumi, -pākku, -tābā(包), (パック), 束

- tsu

-hon

本

-hon

本

-hon

本

\section{DISCUSSION}

Newār and Japanese are two languages, which though genetically unrelated, are similar in the constraints they place upon the numeric 
quantification of nouns. It is not grammatical in either of these languages to quantify nouns directly through the use of numerals. In order to quantify a noun numerically, it is necessary to affix the numeral with a counting unit (Classifier) in congruence to the parameters of the head noun being counted in both Newār and Japanese, but the way in which nouns are classified for numeric quantification in the two languages differs. In this context classifiers of Newār and Japanese may be differentiated as follows:

(i) classifiers that are used in the quantification of sets of nouns, based upon semantic features (such as shape, occurrence in pairs and other attributes), (ii) classifiers that are used in the quantification of sets of nouns, based upon semantic features shared by the members of their respective sets on the one hand and (iii) classifiers that collocate uniquely with individual nouns (as -khā does with chẽ 'house'). We cannot really claim that the uniquely collocating classifiers "classify" the nouns they quantify according to semantic features. Each goes together with only a single noun head so the semantic content of the collocation cannot be tested. Reduplicative classifiers form a sub-type of the uniquely collocating classifiers, and with this sub-type the classifier is a reduplication of the noun-head. Classifier and the quantified noun head are related not by semantic features, but rather by a morphological derivation from the head. The relation is formal, not semantic.

In both Newār and Japanese objects are classified based mainly upon their shape, size, activities, and nature. However, only a single Newār classifiermha is used to count all animate objects. Seven Japanese Counterparts -nin (人), -hiki (匹), -tou (頭), -wā (羽), -ri (人), -mei (名), -shi (氏),-tāi (体) and-wā (羽) depending upon sizes, habitats and nature of the objects.

Japanese classifiers seem to be particular for counting inanimate objects of different nature such as letters and documents; explosives fire crackers; cut pieces or broken pieces; monuments and graves; houses and buildings; small 3-dimensional objects; means of navigation of land; water and air; items; parts and copies.

Newār classifier -gu: is the counterpart for many different Japanese classifiers.viz. Japanese classifier -tsu for counting abstract nouns; Japanese classifier -tsuu (通) for counting letters and documents meant for dispatch; Japanese classifiers -ken (軒), -mune (棟), -tou (棟) for counting houses and buildings of different shapes and purposes; Japanese classifier-ten (点) for counting items; and Japanese classifier-bu (部) for counting parts and copies.

Newār classifier -ga: is the counterpart for many different Japanese classifiers. viz. Japanese classifier -hātsu” in Japanese) (発) for counting bullets, explosives and fire crackers; Japanese classifier -sou(艘) for counting small ships; Japanese classifier tei (艇) for counting for race boats like yachts; Japanese classifier-seki (隻) for counting for big ships. 
Newār classifiers -gu: and -ga: are mutually used as counterparts of the Japanese classifier -ki ( 基) used to count monuments, but, only -gu: is permissible for counting graves.

Newār classifier-ku: is the counterpart for the Japanese classifier -hen (片) used to count Cut pieces or broken pieces.

Newār classifiers-cā:, -pvā: , -pu are the counterparts of the Japanese classifier -ko(個) used to count small 3-dimensional objects (Adams, 1982; DeLancey, 1986; Erbaugh, 1986) .

Newār classifier-phva: is the counterpart for the two Japanese classifiers: hon (本) used for counting flowers with stalk, -rin (輪) for counting stalkless flowers.

Newār classifier-mā is the counterpart of the Japanese classifier-hon (本) used for counting trees, grasses and vines. for animals.

-ko (個) and -hiki (匹) are the most commonly used Japanese classifiers

-ga: and -gu: are the most commonly used Newār classifiers for counting inanimate objects of different shapes and nature.

Japanese classifier -tāmā (玉) classifies cauliflower (a vegetable with a bulb).

Cannon is one lone object classified by a specific lone classifier -mon (門) in Japanese. There is no such specific lone classifier for cannon in Newār.

Japanese classifier -kātāhou ((片方) which means “A side/ A row (of a desk etc)" classifies one of "Paired objects" such as a hand, a leg, a sock, a shoe etc (Kazou, 1994). However, there are two ways in which this classifier may be used, in terms of order:

(a) The classifier immediately followed by the object with a possessive particle /no/ (の) before the object. For example

-kātāhou $($ 片方 $)+/$ no/ + Object. e.g. kātāhouno te/āshi/me = 'one hand'/ 'one leg'/ 'one eye'.

(b) The classifier after the object with a particle /wo/ in between it and the verb in the sentence. For example

Object + -kātāhou $($ 片方 $)+$ /wo/ + Verb.

'tebukuro -kātāhou wo nākushitā' = 'Lost one piece of a pair of gloves'.

The number of Japanese reduplicative classifiers is far lesser than Newār classifiers with exceptions of few in terms of the repetitions of the classifiers (either fully or partially) while counting objects.

This paper will serve as a landmark in terms of the scope and dimensions in the field of comparative study of Newār classifiers and Japanese classifiers as it has identified new findings totally unknown previously in the arena of Newār and Japanese classifiers except (i) the contributor's MA dissertation entitled "Nepālbhās $\bar{a}$ wo 
jāpānibhāsāyā tājigva: yātulanātmak adhyayan" [comparative study of Newār and Japanese classifiers] of 2007-08 submitted to Tribhuvan University, Department of Nepāl bhāsāa, the first ever of its kind and horizon, (ii) Dr. Rudra Laxmi Shrestha's identification of only 21 Japanese classifiers with no mentioning of the Chinese scripts of the Japanese classifiers in her article, 2004, (iii) Kazuyuki Kiryu's work, 2002 with Chinese scripts for every translation of Newār words into Japanese and vice-versa, but with no particular mentioning about classifiers of both languages in his book .

Hope this paper will have an indelible impact in the field of comparative study of Newār classifiers and Japanese classifiers in the days to come.

\section{CONCLUSIONS}

The following new discoveries made in the comparative study of the two languages have been presented for the first time in this article:

Parameters (common characteristics) of the objects concerned attributing to the use/s of particular classifier or classifiers of both languages, Reduplicative classifiers of both languages, More than seven classifiers for counting animate objects in Japanese- unlike only one in Newār (Excepting classifiers for counting plants),Uses of Newār classifier -mā for plants and trees $\sim$ Japanese classifier hon, Japanese classifiers -rin(輪) for stalkless flowers and -hon(本) for stalked flowers $\sim$ classifier -phva :, Japanese classifier -kātāhou (片方) for counting "one of paired body parts" such as "an eye", "A leg", "a hand", and other objects such as "a glove" etc with explanations of how the classifier may be used in two different ways in terms of its order, The way how a set of nouns attains countability through reduplication in one language may differ from the semantic counterparts in the other language which might attain countability through attributive modification by a discrete numeral classifier. For instance, none of the Newār reduplicative head nouns-kica: - (shadow) -tsu; , -ti - (stitch) -ko, -hon; duvā: - (door or entrance of a court-yard) -ki, -mon; palā: - (step) -ho; -pva: - (swelling, heap of/ pile of) --kāsho, -tsu , -pāa - (feather, axe) -māì, -cyou, -pu - (seed) -tsubu (cubu); -pafi - (finger) -hon; -pi - (placenta) tsu , phi (sand) -hāi; , ha: - ( leaf) -māi , pva: (a swelling) -kāsho have their reduplicative counterparts (of full - reduplication) in Japanese . Nor anyone of the Newār reduplicative classifiers-khvāẽ - pālikhvāẽ chakhvāẽ (one footprint); nakĩ -nakĩ chakĩ (one iron nail); pi -durupi chapi(one nipple); pi - cupi chapi (a knife, a chopper ); phi -tuphi chaphi (a broom); pva: - bhõ: pva: chapva:(a bundle of papers); pva: -durupva: chapva:(a breast); pvā: -simāpvā: chapvā: (one crotch of a tree); pvā: , dhã:pvā: chapvā:(a gutter) have their counterparts (of partial - reduplication) in Japanese.

However, the following reduplicative classifiers of both the languages enjoy their mutual corresponding counterparts:

Japanese classifier -ori (折)-(pleat) Newār classifier -mva:; Japanese classifier -retsu (列)-(row) Newār classifier -jhva:; Japanese classifier -gyou (行)-(line of sentences etc) 
Newār classifier -dhva:; Japanese classifier -teki (滴)-(drop) Newār classifier -phuti ; Japanese classifier -shijuku (雫 / 滴)-(drop) Newār classifier phuti; Japanese classifier -dānrāku (段落) -(paragraph) Newār classifier tyāka: .

\section{ACKNOWLEDGEMENTS}

I am indebted to Dr. Terashima Takashi for his teachings about Japanese Classifiers. My sincere thanks go to Austin Hale, Switzerland for looking over my article.

\section{WORKS CITED}

Adams, C.F. 1982. Altaic Languages. Wikipedia free encyclopedia.

DeLancey. 1986. Altaic Languages. Wikipedia free encyclopedia.

Erbaugh. 1986. Altaic Languages. Wikipedia free encyclopedia.

Hale, A. and S. Iswaranand. 1973. Is Newāri a Classifier Language? Contributions to Nepalese Studies. 1:1-21.

Hale, A. and K. P. Shrestha 2005. Newār (Nepāl Bhāsā). Numeral Classifiers. True Classifiers. Pages 49-51. Muenchen. LINCOM GmbH Gmunder Str. 35 D-81379.

(http://ja.wikipedia.org/wiki/\%E5\%8A\%A9\%E6\%95\%B0\%E8\%A9\%9E). $\quad 14^{\text {th }}$ October 2008.

Iida A. 2004. Khājoe kātāno jiten. Shogakukan, Tokyo. Pages 397.

Kiryu, K. 2002. Newārugo goi shuu. Tokyo University of Asian and African Languages and Culture Research Institute. Tokyo. Pages 164.

Asano, T., Y. Morita, S. Saitou, Y. Sakata, S. Suzuki, and K. Takahashi. 1994.

Gāikokujinnnotāmeno kihon'go yourei jiten. $3^{\text {rd }}$ Edition Agency for Cultural Affairs, Tokyo. Pages 1023.

Shrestha, A. 2008. Nepālbhāṣāyā tājigva:yā tulanātmak adhyayan. 2008. M.A. dissertation. Tribhuvan University, Kirtipur, Nepal. Page 146.

Shrestha, A. 2009. Comparative study of Newari and Japanese Classifiers. Paper presented at the $30^{\text {th }}$ Annual conference of Linguistics Society of Nepal Tribhuvan University, Kirtipur, Nepal. Pages 12.

Shrestha, R. L. 2004. Classifiers of Nepāl Bhāsā in the Context of Chinese and Japanese Languages. Nepāl Bhāsā anusandhānmulak patrikā. Nepāl bhās̄a Kendriya bibhāg 2: 100-113.

Umesao, T., H. Kindaichi, A. Sakakura, and S. Hinohara. 1989.Nihongo dai jiten. Kodansha Colour Publications., Tokyo. Pages 2305. 